\title{
Decidual endothelial cells express surface-bound C1q as a molecular bridge between endovascular trophoblast and decidual endothelium
}

\author{
Roberta Bulla ${ }^{\text {a }}$, Chiara Agostinis ${ }^{a}$, Fleur Bossi ${ }^{\text {a }}$, Lucia Rizzi ${ }^{\text {a }}$, Alessandra Debeus ${ }^{\text {a }}$, \\ Claudio Tripodo ${ }^{\mathrm{b}}$, Oriano Radillo ${ }^{\mathrm{c}}$, Francesco De Seta ${ }^{\mathrm{d}}$, \\ Berhane Ghebrehiwet ${ }^{\mathrm{e}}$, Francesco Tedesco ${ }^{\mathrm{a}, *}$ \\ a Department of Physiology and Pathology, University of Trieste, via Fleming 22, 34127, Trieste, Italy \\ ${ }^{\mathrm{b}}$ Department of Human Pathology, University of Palermo, Palermo, Italy \\ ${ }^{\mathrm{c}}$ Laboratory of Clinical Analysis, IRCCS Burlo Garofolo, Trieste, Italy \\ d Department of Reproductive and Developmental Sciences, IRCCS Burlo Garofolo, University of Trieste, Trieste, Italy \\ e Department of Medicine, SUNY at Stony Brook, NY, USA
}

Received 22 November 2007; received in revised form 21 December 2007; accepted 24 December 2007 Available online 4 March 2008

\begin{abstract}
This study was prompted by the observation that decidual endothelial cells (DECs), unlike endothelial cells (ECs) of blood vessels in normal skin, kidney glomeruli and brain, express surface-bound C1q in physiologic pregnancy. This finding was unexpected, because deposits of C1q are usually observed in pathologic conditions and are associated with complement activation. In the case of DECs, we failed to detect immunoglobulins and C4 co-localized with C1q on the cell surface. Surprisingly, DECs expressed mRNA for the three chains of C1q and secreted detectable level of this component in serum-free medium. The ability to synthesize C1q is acquired by DECs during pregnancy and is not shared by ECs obtained from endometrium and from other sources. Cell-associated C1q has a molecular weight similar to that of secreted C1q and is released from DECs following treatment with heparinase or incubation at low $\mathrm{pH}$. This suggests that $\mathrm{C} 1 \mathrm{q}$ binds to DECs and it is not constitutively expressed on the cell surface. C1q is localized at contact sites between endovascular trophoblast and DECs and acts as an intercellular molecular bridge because adhesion of endovascular trophoblast to DECs was inhibited by antibodies to C1q and to a receptor recognizing its globular portion expressed on trophoblast.
\end{abstract}

(C) 2008 Elsevier Ltd. All rights reserved.

Keywords: C1q; Trophoblast; Endothelial cells; Glycosaminoglycans

\section{Introduction}

Endothelial cells (ECs) cover the inner surface of the vessel wall and establish continuous interaction with the complement (C) system that may cause their morphologic and functional changes (Fischetti and Tedesco, 2006).

Abbreviations: ECs, endothelial cells; DECs, decidual endothelial cells; UtMEC, uterine microvascular endothelial cells; ADMECs, human dermal microvascular endothelial cells; C, complement; PMN, neutrophils; CTBs, cytotrophoblasts; vWF, von Willebrand Factor; IL, interleukin; GAGs, glycosaminoglycans.

* Corresponding author. Tel.: +39 0405584037; fax: +390405584023.

E-mail address: tedesco@units.it (F. Tedesco).
$\mathrm{C}$ activation products are responsible for these changes and include the anaphylotoxins $\mathrm{C} 3 \mathrm{a}$ and $\mathrm{C} 5 \mathrm{a}$, that bind to specific receptors on ECs (Monsinjon et al., 2003; Schraufstatter et al., 2002), and the terminal C complex that interacts with ECs either as a sublytic membrane attached complex (Hattori et al., 1989) or as cytolytically inactive complex (Tedesco et al., 1997). Expression of adhesion molecules and tissue factor, release of chemokines, increased permeability are some of the responses of ECs to these factors (Bossi et al., 2004; Dobrina et al., 2002; Kilgore et al., 1996; Selvan et al., 1998) and both C5a and SC5b-9 have been shown to promote transendothelial migration of PMN (Dobrina et al., 2002). However, under normal conditions the endothelium is protected from the stimulating effect of $\mathrm{C}$ activation products that induce a pro-inflammatory and pro-coagulant state by the regulatory proteins CD46, CD55 
and CD59 expressed on their surface and the fluid phase regulator Factor H that binds to ECs (Asch et al., 1986; Hamilton et al., 1990; Jokiranta et al., 2005; McNearney et al., 1989).

ECs also represent a potential target of C1q and MBL, two recognition molecules of the $\mathrm{C}$ system that share a similar molecular structure and are made of globular and collagen regions (Oroszlan et al., 2007). Data collected from various groups over the last decade have shown that immune complexes (IC)-bound C1q stimulates the expression of adhesion molecules on EC (Lozada et al., 1995) and also that free C1q induces cell adhesion and spreading (Feng et al., 2002) and production of IL8, IL-6 and monocyte chemoattractant protein-1 (van den Berg et al., 1998). The effects mediated by free C1q have been shown to involve the interaction of $\mathrm{C} 1 \mathrm{q}$ with $\mathrm{C} 1 \mathrm{q}$ receptors expressed on the surface of ECs (Peerschke et al., 1993; Peerschke et al., 1996). Under physiological conditions, approximately $10 \%$ of $\mathrm{C} 1 \mathrm{q}$ circulates as free molecule while the majority of $\mathrm{C} 1 \mathrm{q}$ is a part of $\mathrm{C} 1$ complex together with $\mathrm{C} 1 \mathrm{r}$ and $\mathrm{C} 1 \mathrm{~s}$ (Ziccardi and Tschopp, 1982). C1q not associated with C1r and C1s is also available following $\mathrm{C}$ activation by immune complexes which results in binding of $\mathrm{C} 1$ and release of $\mathrm{C} 1 \mathrm{r}$ and $\mathrm{C} 1 \mathrm{~s}$ mediated by C1 inhibitor (Ziccardi and Cooper, 1979). The in vivo finding that $\mathrm{C} 1 \mathrm{q}$ is required for deposition of immune complexes on the vessel wall (Stokol et al., 2004) confirms similar observations made in vitro on human umbilical vein endothelial cells (HUVECs) (Daha et al., 1988). In the present investigation we show that $\mathrm{C} 1 \mathrm{q}$ is present in vivo under physiologic conditions on ECs of decidual vessels and is used to promote cell-cell interaction.

The decidua is a newly formed tissue on the maternal side of human placenta and is characterized by active angiogenesis and structural modifications of the spiral arteries in the early phase of pregnancy. These changes, that include gradual loss of the musculoelastic structure of the arterial wall and the replacement by amorphous fibrinoid material, are essential to create vessels of low resistance that are unresponsive to vasoconstrictive agents (Lyall et al., 2001; Pijnenborg et al., 2006) allowing continuous blood flow in the intervillous space. Failure of spiral artery to undergo transformation may lead to a spectrum of pregnancy failures including pre-eclampsia (Zhou et al., 1997a), foetal growth restriction and miscarriage (Michel et al., 1990; Sheppard and Bonnar, 1981).

An additional feature of the physiologic changes of spiral arteries is the endovascular invasion of extravillous trophoblast that adheres to and replaces ECs giving rise to mosaic vessels in which trophoblast and ECs coexist (Bulla et al., 2005). We now present data indicating that decidual ECs (DECs) synthesize and express $\mathrm{C} 1 \mathrm{q}$ on their surface, a unique feature that is not shared by other ECs under physiologic conditions. Furthermore, this $\mathrm{C}$ component binds to DECs and is used as a molecular bridge to promote trophoblast adhesion.

\section{Materials and methods}

\subsection{Antibodies and reagents}

Two monoclonal antibodies (mAbs) anti-gC1q receptors (gC1qRs) (clones 74.5.2 and 60.11) recognizing distinct domains of the molecule and rabbit anti-human $\mathrm{cC} 1 \mathrm{q}$ receptor $(\mathrm{cClqR})$ were previously reported (Ghebrehiwet et al., 1996). Goat antiserum to $\mathrm{C} 1 \mathrm{q}, \mathrm{C} 3$ and $\mathrm{mAb}$ to human $\mathrm{C} 1 \mathrm{q}$, $\mathrm{C} 4 \mathrm{c}$ and purified $\mathrm{C} 1 \mathrm{q}$ were purchased from Quidel (San Diego, CA). MAb85 anti-C1q was a kind gift of M. Loos (Mainz, Germany) and goat IgG anti-human C1q were purchased from The Binding Site (Roma, Italy). Rabbit anti-human C1q, mAb OV-TL 12/30 anti-cytokeratin 7, mAb 6.5B5 antiICAM-1 and mAb F8/86 anti-von Willebrand Factor (vWF) were from Dako (Milano, Italy), while mAb QBEnd/10 antiCD34 and rabbit anti-human IgG and IgM were obtained from Novocastra-Menarini (Firenze, Italy). mAb M89D3 to CD31 was kindly provided by M.R. Zocchi (San Raffaele Hospital, Milan, Italy) (Dobrina et al., 2002). Mouse IgG1 isotype control was from Sigma-Aldrich (Milano, Italy) and mAb MEM-G9 anti-human leukocyte antigen G (HLA-G) was a kind gift of P. Le Bouteiller (Toulouse, France). The IgG were purified from the antisera by affinity chromatography on protein G-Sepharose column (Pharmacia, Milano, Italy). The following secondary antibodies were used: FITC-conjugated $\mathrm{F}\left(\mathrm{ab}^{\prime}\right)_{2}$ fragment of goat anti-mouse Ig and FITC-labeled swine IgG anti-rabbit Ig were from Dako; alkaline-phosphatase (AP)-conjugated goat IgG directed to mouse $\mathrm{IgG}$ and rabbit $\mathrm{IgG}$, and AP-conjugated streptavidine were purchased from Sigma-Aldrich.

\subsection{Tissues samples}

Samples of first trimester placenta were collected from women undergoing voluntary termination of pregnancy at 8-12 weeks' gestation. Endometrial tissue specimens were obtained from fertile women undergoing hysterectomy for leiomyomatosis in the mid proliferative and mid secretory phase defined according to Noyes criteria (Noyes et al., 1975). Brain and kidney tissue samples were collected from the peri-tumoral parenchyma of low-grade gliomas and renal cell carcinomas, respectively. Skin samples were obtained from patients undergoing reductive plastic surgery. The study was approved by the institutional review board of The Maternal-Children's Hospital (IRCCS "Burlo Garofolo", Trieste, Italy) and informed consent was obtained from all patients providing the tissue specimens.

\subsection{Histopathology and immunohistochemical staining}

Tissue samples were fixed in $10 \%$ buffered formalin and paraffin embedded. Four-micrometers-thick sections of placental tissue were stained with hematoxylin-and-eosin and examined for the presence and distribution of invasive and endovascular trophoblast. For immunohistochemical analysis, the slides were microwaved three times in Tris-HCl/EDTA (ethylenediamine tetraacetic acid) $\mathrm{pH} 9.0$ buffer (Dako) for $5 \mathrm{~min}$, brought to room temperature, and washed in phosphate buffered saline (PBS). After neutralization of the endogenous peroxidase with $\mathrm{H}_{2} \mathrm{O}_{2}$ for $10 \mathrm{~min}$, the sections were first incubated with protein block (Novocastra) for $10 \mathrm{~min}$ and then with the primary antibodies for $1 \mathrm{~h}$ at room temperature. The bound antibodies were revealed using the Labeled StreptAvidin Biotin (LSAB)+ horseradish peroxidase (HRP) kit and 
diaminobenzidine (DAB) as substrate (Dako). Triple immunohistochemical staining was performed according to Lan et al. with some modifications (Lan et al., 1995). Sections underwent sequential immunostaining with $1 / 100$ rabbit anti-human-C1q (Dako), 1/50 mAb OV-TL 12/30 anti-human-cytokeratin 7 (Dako), and 1/50 mAb QBEnd/10 anti-human-CD34 (Novocastra) to visualize $\mathrm{C} 1 \mathrm{q}$, trophoblast and endothelial cells respectively. Anti-C1q binding was detected using the LSAB+ HRP kit (Dako) and DAB as chromogen; anti-cytokeratin 7 was revealed by the Alkaline Phosphatase Anti-Alkaline Phosphatase (APAAP) Complex (Dako) and BCIP (5-Bromo-4Chloro-3'-Indolyphosphate $p$-Toluidine Salt)/NBT (Nitro-Blue Tetrazolium Chloride) as chromogen; anti-CD34 with the Peroxidase Anti-Peroxidase (PAP) Mouse Monoclonal Complex (Dako) and AEC ( $\beta$-amino-9-ethyl-carbazole) as chromogen. The sections were counterstained with hematoxylin.

Slides were evaluated under a Leica DM3000 optical microscope (Leica, Germany) and images were collected using a Leica DFC320 digital camera (Leica). All the immunohistochemical analysis were performed on three different tissue samples.

\subsection{Cell isolation and culture}

DECs were isolated from decidual biopsy specimens as previously described with some modifications (Bulla et al., 2005). Briefly, the tissue was finely minced, digested first with $0.25 \%$ trypsin (Sigma-Aldrich) and $50 \mu \mathrm{g} / \mathrm{ml}$ DNase I (Roche, Milano, Italy) overnight at $4{ }^{\circ} \mathrm{C}$, and then with collagenase type $1(3 \mathrm{mg} / \mathrm{ml})$ (Worthington Biochemical Corporation, DBA, Milano, Italy) for $30 \mathrm{~min}$ at $37^{\circ} \mathrm{C}$. The cells collected at the interface of Ficoll-Paque gradient (Pharmacia), after centrifugation of the cell suspension at $690 \times g$ for $30 \mathrm{~min}$, were positively selected with Dynabeads M-450 (Dynal, Invitrogen, Milano, Italy) coated with Ulex europaeus 1 lectin (Sigma-Aldrich). Cytofluorimetric analysis showed that more than $95 \%$ of the cells stained for vWF (Dako). The cells were seeded in $12.5-\mathrm{cm}^{2}$ flask precoated with $5 \mu \mathrm{g} / \mathrm{cm}^{2}$ fibronectin (Roche) and maintained in endothelial serum-free basal medium (GIBCO, Invitrogen) supplemented with $20 \mathrm{ng} / \mathrm{ml}$ bFGF (basic Fibroblast Growth Factor) and $10 \mathrm{ng} / \mathrm{ml}$ EGF (Epidermal Growth Factor) (GIBCO, Invitrogen).

Uterine microvascular endothelial cells (UtMECs) were purified from endometrial tissue samples by a similar procedure.

Human dermal microvascular endothelial cells (ADMECs) were isolated as previously described by Kraling et al. (1994) and seeded on $35 \mathrm{~mm}$ culture dishes coated with $5 \mu \mathrm{g} / \mathrm{cm}^{2}$ fibronectin (Roche) in Medium 199 supplemented with 10\% New Born Calf Serum (NBCS), 10\% human serum, cAMP ( $3^{\prime}-5^{\prime}$-cyclic adenosine monophosphate) $25 \mu \mathrm{g} / \mathrm{ml}$, hydrocortisone $1 \mu \mathrm{g} / \mathrm{ml}$, heparin $50 \mu \mathrm{g} / \mathrm{ml}$ (Sigma-Aldrich) and EGF $10 \mathrm{ng} / \mathrm{ml}$ (GIBCO, Invitrogen). ADMECs were further purified from a subconfluent mixed cell population with the magnetic beads Dynabeads CD31 (Dynal, Invitrogen).

HUVECs were isolated from umbilical cord veins as previously published (Tedesco et al., 1997). All endothelial cells were used at their second or third passage of culture.
Cytotrophoblasts (CTBs) were purified from placental tissue incubated with Hanks' Balanced Salt Solution (HBSS) containing $0.25 \%$ trypsin and $0.2 \mathrm{mg} / \mathrm{ml}$ DNase I (Roche) for $20 \mathrm{~min}$ at $37^{\circ} \mathrm{C}$, following a previously published procedure (Bulla et al., 2005). The cells were seeded on $25-\mathrm{cm}^{2}$ flask precoated with $5 \mu \mathrm{g} / \mathrm{cm}^{2}$ fibronectin (Roche) in RPMI (GIBCO, Invitrogen) supplemented with $10 \%$ foetal calf serum (FCS) to remove non-adherent leucocytes and syncitiotrophoblasts, and used within $12 \mathrm{~h}$. The cells were $95 \%$ positive for cytokeratin 7 and $70 \%$ positive for HLA-G by cytofluorimetric analysis.

\subsection{RNA isolation, $c D N A$ synthesis and reverse transcriptase polymerase chain reaction (RT-PCR)}

Cultured cells and finely minced decidual tissue were harvested in Omnizol (Euroclone, Milano, Italy) according to the supplier's instructions. Total RNA was extracted with chloroform and precipitated with isopropanol by $12,000 \times g$ centrifugation at $4{ }^{\circ} \mathrm{C}$. To digest contaminant genomic DNA, RNA samples were treated with 5 Units DNase RNase free (Sigma-Aldrich), re-extracted with Omnizol/chloroform and precipitated with isopropanol. The RNA pellet was washed with $75 \%$ ethanol, resuspended in diethylpyrocarbonate-treated water and quantified by light absorbance at $260 \mathrm{~nm}$. First strand cDNA was synthesized from $2 \mu \mathrm{g}$ total RNA using the SuperScript II Reverse Transcriptase kit (Invitrogen) with random hexanucleotide primers (Roche), according to the manufacturer's instructions. Polymerase chain reaction (PCR) was performed with Taq DNA polymerase (AccuTaq, Sigma-Aldrich), and $1 \mu 1$ cDNA in a Techne TC-312 thermal cycler (Boneworld Scientific, Milano, Italy). Table 1 lists the primers used for PCR following Kaul and Loos (2001). PCR products were run through a $1.5 \%$ agarose gel containing ethidium bromide for ultraviolet detection.

\subsection{Enzyme-linked immunosorbent assay (ELISA)}

EC-bound C1q was assessed on cells grown to confluence in 96-well tissue culture plates (Costar, Cambridge, MA). The cells were incubated with $100 \mu \mathrm{l}$ of optimal dilution of the primary antibodies for $1 \mathrm{~h}$ at room temperature followed by AP-conjugated secondary antibodies (Sigma-Aldrich). The enzymatic reaction was developed with PNPP ( $p$-nitrophenyl phosphate) (Sigma-Aldrich; $1 \mathrm{mg} / \mathrm{ml}$ ) as substrate and read kinetically at $405 \mathrm{~nm}$ using a Titertek Multiskan ELISA reader (Flow Labs, Milano, Italy).

The acid strip procedure was performed according to Heigler et al. on DECs grown to confluence in 96-well tissue culture plates (Costar). The cells were incubated with $100 \mu \mathrm{l}$ of $0.2 \mathrm{M}$ $\mathrm{Na}$ acetate buffer containing $150 \mathrm{mM} \mathrm{NaCl}$ at $\mathrm{pH} 2.5,3.5$, or 7.5 for $10-15 \mathrm{~s}$ on ice and neutralized by the addition of $10 \mu \mathrm{l}$ of $1 \mathrm{M}$ Tris $\mathrm{pH}$ 9. In other experiments the cells were incubated in $\mathrm{dPBS}$ containing $1 \mathrm{M} \mathrm{KCl}$ for $45 \mathrm{~s}$ at $4{ }^{\circ} \mathrm{C}$. The residual cell-bound $\mathrm{Clq}$ was evaluated by ELISA (see above).

C1q secreted by ECs in the supernatant was measured by a sandwich ELISA as previously described (Langeggen et al., 
Table 1

Primers used for PCR analysis in accord to the method of Kaul and Loos (2001)

\begin{tabular}{llllll}
\hline Sample & Primers & Sequence $5^{\prime} \rightarrow 3^{\prime}$ & Annealing temperature $\left({ }^{\circ} \mathrm{C}\right)$ & Size of PCR product $(\mathrm{bp})$ & EMBL accession number \\
\hline$\beta$-Actin & $\begin{array}{l}\text { Forward } \\
\text { Reverse }\end{array}$ & $\begin{array}{l}\text { CTACAATGAGCTGCGTGTGG } \\
\text { AAGGAAGGCTGGAAGAGTGC }\end{array}$ & 59 & 528 & M 10278 \\
C1qA & $\begin{array}{l}\text { Forward } \\
\text { Reverse }\end{array}$ & $\begin{array}{l}\text { ATGGTGACCGAGGACTTGTG } \\
\text { GTCCTTGATGTTCCTGGGC }\end{array}$ & 62 & 276 & BC071986 \\
& Forward & ACCCCAGGGATAAAAGGAGAG & 60 & 216 & BC008983 \\
C1qB & $\begin{array}{l}\text { Reverse } \\
\text { GGCAGAGAAGGCGATTTTCTG }\end{array}$ & & 213 & NM_172369 \\
C1qC & $\begin{array}{l}\text { Forward } \\
\text { Reverse }\end{array}$ & AAGGATGGGTACGACGGACTG & 65 & & \\
& TTTCTGCTTGTATCTGCCCTC & & & \\
\hline
\end{tabular}

2000) using goat IgG anti-C1q to bind $\mathrm{C} 1 \mathrm{q}$ and the same antibody labeled with biotin to reveal bound C1q followed by AP-conjugated streptavidin (Sigma-Aldrich).

\subsection{Flow cytometry}

ECs and CTBs were detached from culture flasks with $5 \mathrm{mM}$ EDTA at $37^{\circ} \mathrm{C}$ and a total number of $5 \times 10^{5}$ was incubated with the relevant primary antibodies for $1 \mathrm{~h}$ at $37^{\circ} \mathrm{C}$ followed by FITC-conjugated goat $\mathrm{F}\left(\mathrm{ab}^{\prime}\right)_{2}$ anti-mouse Ig or swine anti rabbit $\operatorname{IgG}(\mathrm{Dako})$. The cells were fixed with $1 \%$ paraformaldehyde (Sigma-Aldrich) and analysed for fluorescence on a FACScalibur instrument (BD Biosciences, Milan, Italy) using CellQuest software.

\subsection{Preparation of cell lysate}

Confluent monolayers of DECs grown in a $150 \mathrm{~cm}^{2}$ flask were washed with warm PBS and incubated with $1 \mathrm{ml}$ sulphoNHS-LC-biotin (sulphosuccinimidyl-6-biotinamidohexanoate, Sigma) $(1 \mathrm{mg} / \mathrm{ml})$ for $20 \mathrm{~min}$ at room temperature. After removing excess biotin, the cells were lysed with $\mathrm{pH} 8$ buffer containing $50 \mathrm{mM}$ Tris- $\mathrm{HCl}, 250 \mathrm{mM} \mathrm{NaCl}, 0.5 \%$ NP40 (Nonidet-P40), and $1 \mathrm{mM}$ PMSF (phenylmethylsulphonyl fluoride) on ice (Kaul and Loos, 2001). The cell lysate $\left(10^{6}\right.$ cells $\left./ \mathrm{ml}\right)$ was centrifugated $\left(40 \mathrm{~min}, 12,000 \times g, 4^{\circ} \mathrm{C}\right)$ to remove nuclei and cellular debris and the supernatant containing the labeled proteins was collected. The protein content was estimated using the Bradford dye-binding method (BioRad Labs., Richmond, CA) (Bradford, 1976) and the degree of biotinylation assessed by dot spot assay using AP-conjugated streptavidin.

The cell lysate was examined for the presence of $\mathrm{gClqR}$ and cC1qR by a capture ELISA coating microtiter plates (Corning Costar) with $100 \mu$ l of anti-gC1q-R74, anti cClqR or nonimmune, species-matched control $\mathrm{IgG}(10 \mu \mathrm{g} / \mathrm{ml})$ in carbonate buffer, pH 9.5 overnight at $4{ }^{\circ} \mathrm{C}$. After washing, $100 \mu \mathrm{l}$ of biotinylated EC membranes ( $300 \mu \mathrm{g} / \mathrm{ml})$ in PBS, $0.05 \%$, Tween $20,0.05 \%$, skim milk were added to each well and incubated overnight at $4{ }^{\circ} \mathrm{C}$. The wells were then washed with PBS containing $0.1 \%$ Tween 20 and the captured proteins were detected using AP-conjugated streptavidin.

\subsection{Immunoaffinity chromatography}

Anti-C1q affinity column was prepared according to the supplier's instructions by coupling goat IgG anti-C1q (Quidel) with Cyanogen Bromide-Sepharose 4B (Sigma-Aldrich). Approximately $6 \mathrm{ml}$ of cell-lysate or $30 \mathrm{ml}$ of DEC supernatant obtained from $2.5 \times 10^{5}$ cells $/ \mathrm{ml}$ cultured for $48 \mathrm{~h}$ were pre-cleared through an unrelated goat IgG anti-human C5 (Quidel) column, and passed through a $1 \mathrm{ml}$ anti-C1q column at a flow rate of $0.5 \mathrm{ml} /$ minute. The bound $\mathrm{C} 1 \mathrm{q}$ was eluted with glycine buffer pH 2.7 and immediately neutralized with $1 \mathrm{M}$ Tris- $\mathrm{HCl}, \mathrm{pH} 9$ at $1: 10$ ratio.

\subsection{Protein electrophoresis and immunoblotting}

Affinity-purified C1q was subjected to SDS-PAGE (Sodium Dodecyl Sulphate-PolyAcrylamide Gel Electrophoresis) on a $15 \%$ gel under reducing conditions according to Laemmli (1970) followed by electrophoretic transfer onto nitrocellulose membrane (Hybond ECL, Amersham, Milano, Italy) using the semidry Semiphor transfer unit (Heifer Scientific Instruments, San Francisco, CA). The membranes were incubated with $1 / 1000$ rabbit $\operatorname{IgG}$ anti-C1q (Dako) for $1 \mathrm{~h}$ at $37^{\circ} \mathrm{C}$ followed by $1 / 20,000$ AP-conjugated anti-rabbit Ig or $1 / 4000$ AP-conjugated streptavidine (Sigma-Aldrich) for $1 \mathrm{~h}$ at $37^{\circ} \mathrm{C}$. The enzymatic reaction was developed using BCIPNBT (Sigma-Aldrich). Rainbow RPN 756 (Amersham) was used as a mixture of molecular markers of known molecular weight.

\subsection{Cytotrophoblasts adhesion assay}

The assay to evaluate adhesion of CTBs to DECs has been previously described (Bulla et al., 2005). Briefly, CTBs $\left(10^{5}\right.$ cells $\left./ 100 \mu \mathrm{l}\right)$ labeled with a fluorescent dye Fast DiI (Molecular Probes, Invitrogen) were incubated with DECs in the presence of neutralizing $\mathrm{mAbs}$ or control $\mathrm{IgG}$ for $30 \mathrm{~min}$ at $37^{\circ} \mathrm{C}$ in an air $/ \mathrm{CO}_{2}$ incubator. After removing non-adherent CTBs, the number of adherent cells was counted with Infinite200 (ABS 544 nm, EM 590 nm) (TECAN Italia S.r.l., Milano, Italy) with reference to a calibration curves established with increasing number of labeled CTBs. 

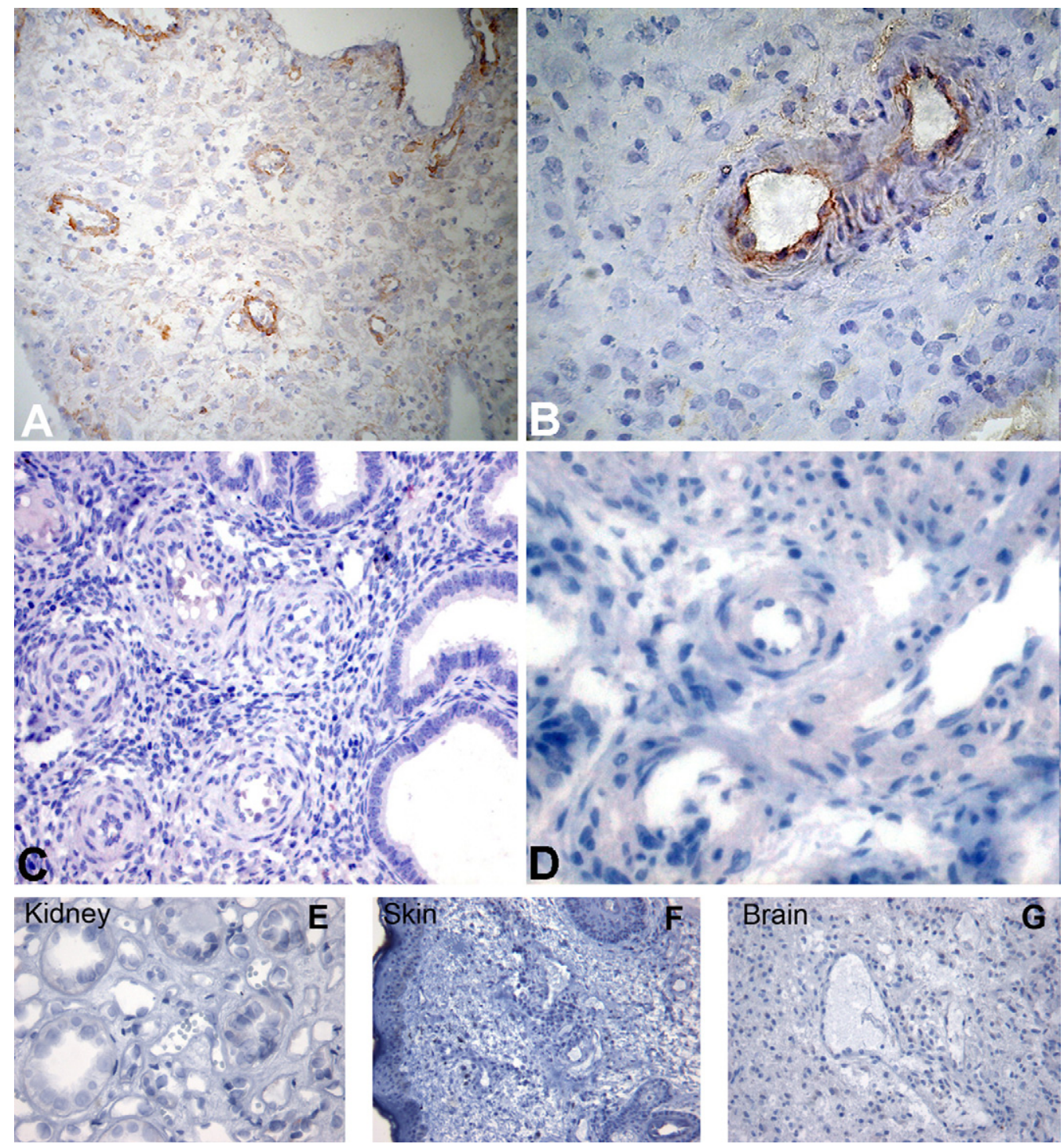

Fig. 1. Detection of $\mathrm{Clq}$ on endothelium of vessels in human decidua, endometrium, skin, brain and kidney glomeruli. Sections of paraffin-embedded maternal decidua (A and B), endometrium (C and D) kidney (E), skin (F), and brain $(\mathrm{G})$ were microwaved and stained for human $\mathrm{C} 1 \mathrm{q}$ using rabbit IgG anti-human $\mathrm{C} 1 \mathrm{q}(1 / 100)$. Bound antibodies were revealed using the LSAB+ HRP kit and DAB as chromogen. The sections were counterstained with hematoxylin. Original magnifications: (A, C, F and G) $200 \times$; (B, D and E) $400 \times$.

\subsection{Statistical analysis}

Data were reported as mean \pm S.D. Student's $t$-test was used to compare two groups of data.

\section{Results}

\subsection{Clq is localized on DECs}

There is conflicting evidence on the deposition of C components in decidual vessels in normal and pathologic pregnancies (Hustin et al., 1983; Kitzmiller et al., 1981; Wells et al., 1987). We have re-examined this issue looking in particular at the presence of $\mathrm{C}$ components on DECs in view of the special interaction of these cells with endovascular trophoblast resulting in their partial replacement. Immunohistochemical analysis of first trimester placentae revealed massive deposition of C1q particu- larly on the endothelium of spiral arteries (Fig. 1A and B) that was not seen in the spiral arteries of endometrium (Fig. 1C and D). Furthermore, we failed to detect $\mathrm{C} 1 \mathrm{q}$ bound to vascular ECs in skin, kidney glomeruli and brain suggesting that under physiologic conditions the deposition of this $\mathrm{C}$ component is restricted to DECs (Fig. 1E-G). To find out if C1q localized on the cell surface was bound to Ig and acted as a recognition molecule for $\mathrm{C}$ activation through the classical pathway, we searched for $\mathrm{IgG}$, IgM and $\mathrm{C} 4$ co-localized with $\mathrm{C} 1 \mathrm{q}$, but we failed to detect these molecules on the endothelium (Fig. 2).

\subsection{Clq is synthesized by DECs and expressed on their surface}

The finding of C1q on the surface of DECs under physiologic conditions in the absence of $\operatorname{IgG}, \operatorname{IgM}$ and $\mathrm{C} 4$ led us to suspect that cell-associated $\mathrm{C} 1 \mathrm{q}$ was synthesized and secreted 

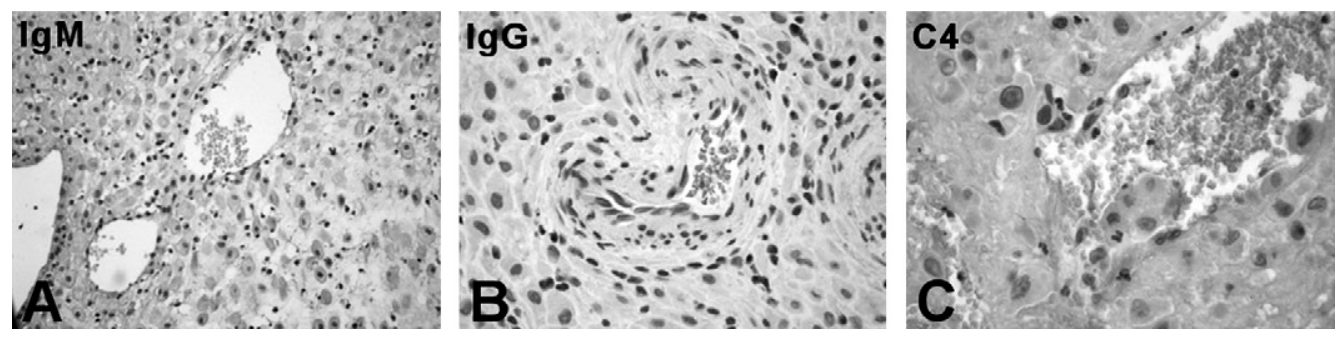

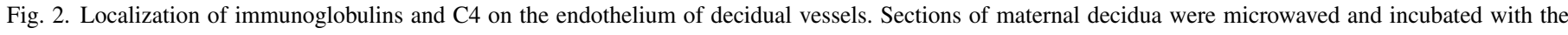

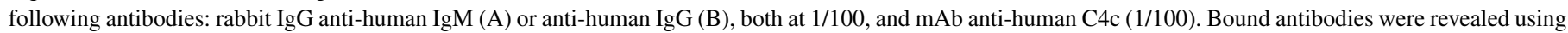
the LSAB+ HRP kit and DAB as chromogen. The sections were counterstained with hematoxylin. Original magnifications: (A) $200 \times$; (B and C) $400 \times$.

by DECs rather than deposited on the cell membrane as a result of $\mathrm{C}$ activation. To prove this, DECs were examined for the expression of mRNA for the three chains of $\mathrm{Clq}$ by RT-PCR and the results were compared with those obtained with ECs from various sources including UtMECs, HUVECs and ADMECs, and also with first trimester decidual tissue. As shown in Fig. 3A, decidua and DECs expressed mRNA for the three chains of C1q, whereas HUVECs and ADMECs expressed only mRNA for the A and B chains, and UtMECs exclusively the mRNA for the A chain. Analysis of mRNA for $\mathrm{A}-\mathrm{C}$ chains of $\mathrm{C} 1 \mathrm{q}$ in different populations of DECs showed some variation in the intensity of the three bands relative to that of $\beta$-actin, and this was particularly evident for A and B chains (Fig. 3B). Expression of mRNA for the three chains of $\mathrm{C} 1 \mathrm{q}$ in DECs is compatible with the synthesis of $\mathrm{C} 1 \mathrm{q}$ by these cells. To confirm this, we examined the cell supernatant for the presence of C1q by ELISA and found detectable amount of this protein that reached levels varying between 50 and $100 \mathrm{ng} / 10^{6}$ cells secreted after $48 \mathrm{~h}$ of culture (data not shown).

Cytofluorimetric analysis revealed that $\mathrm{C} 1 \mathrm{q}$ was present on the surface of DECs. Conversely, we failed to detect $\mathrm{C} 1 \mathrm{q}$ on the cell membrane of HUVECs, UtMECs and ADMECs (Fig. 4A). To extend this observation, different preparations of ECs from various sources were grown to confluence in 96 wells culture plates and analysed by ELISA for the presence of $\mathrm{C} 1 \mathrm{q}$ on their surface. C1q was revealed in measurable amount only on the surface of DECs, though with a large variability, while it was undetectable on HUVECs, UtMECs and ADMECs (Fig. 4B) These data were confirmed using different monoclonal and polyclonal antibodies. Treatment of DECs

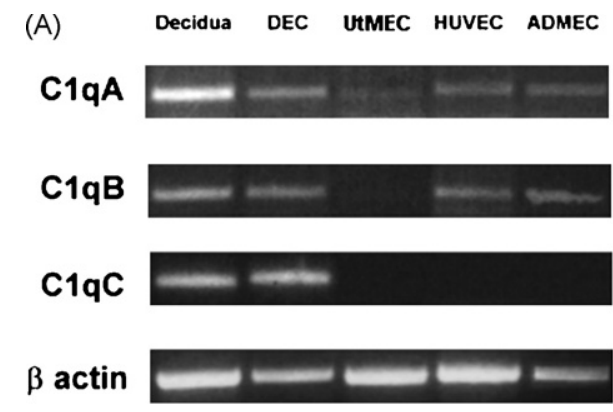

with $5 \mathrm{mM}$ monensin or $0.5 \mathrm{mM}$ brefeldin A for $24 \mathrm{~h}$ to block protein transport through the Golgi complex and secretion totally abolished cell expression of C1q (Fig. 4C) suggesting that cell-associated $\mathrm{Clq}$ was indeed produced by these cells.

\subsection{Characterization of surface-bound Clq}

The detection of substantial amount of C1q on the surface of DECs raised the question whether C1q was an integral membrane protein or was bound to ECs as a peripheral membrane protein. We addressed this issue by analysing the molecular structure of C1q immunoprecipitated from cell lysate, cell supernatant and lysates of biotin-labeled cells by immunoblotting. The SDS-PAGE pattern of C1q purified from cell lysate did not differ from that of secreted $\mathrm{Clq}$ and from the C1q purified from human plasma. In addition, the biotin-labeled $\mathrm{C} 1 \mathrm{q}$ also exhibited the three chains structure with a molecular weight similar to that of released C1q (Fig. 4D). Next, the cells grown to confluence were incubated in medium of progressively lower $\mathrm{pH}$ or $1 \mathrm{M} \mathrm{KCl}$ on ice for $45 \mathrm{~s}$ and the residual $\mathrm{C} 1 \mathrm{q}$ present on the cell membrane was measured by ELISA. Incubation of DECs in $\mathrm{pH} 2.5$ medium led to partial removal of $\mathrm{C} 1 \mathrm{q}$ from the cell surface, while exposure of DECs to high ionic strength buffer was minimally, though significantly, effective suggesting that $\mathrm{C} 1 \mathrm{q}$ was bound to these cells via relatively strong non-covalent interactions (data not shown). One possibility that we consider was that $\mathrm{Clq}$ may interact with $\mathrm{C} 1 \mathrm{qR}$ on the cell membrane. The presence of both these receptors on DECs has been documented by FACS analysis and capture ELISA (Fig. 5A and B). However, we failed to detect either

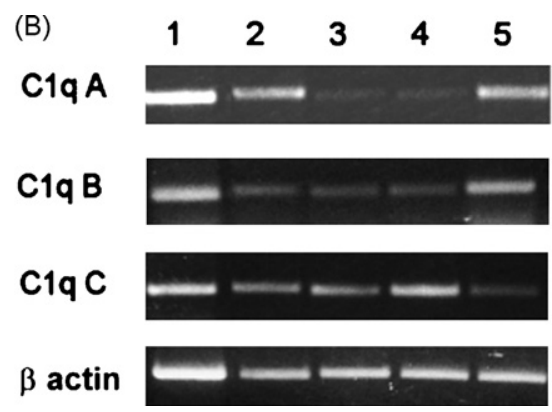

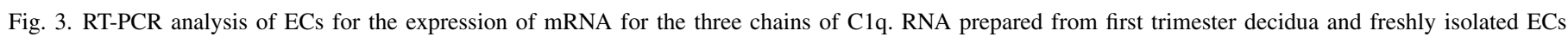

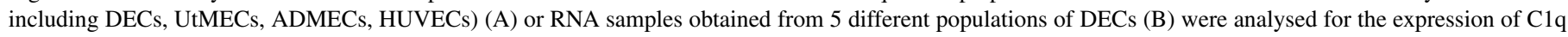
A-C. Analysis of mRNA expression for $\beta$ actin is shown for comparison. 
(A)
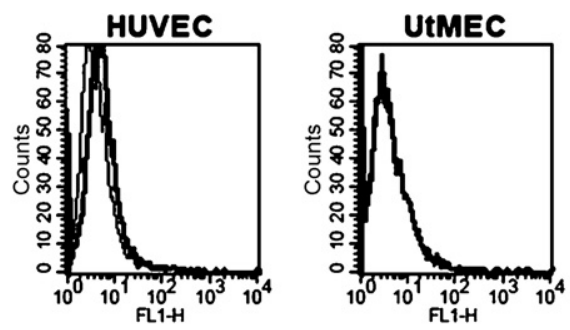

(B)

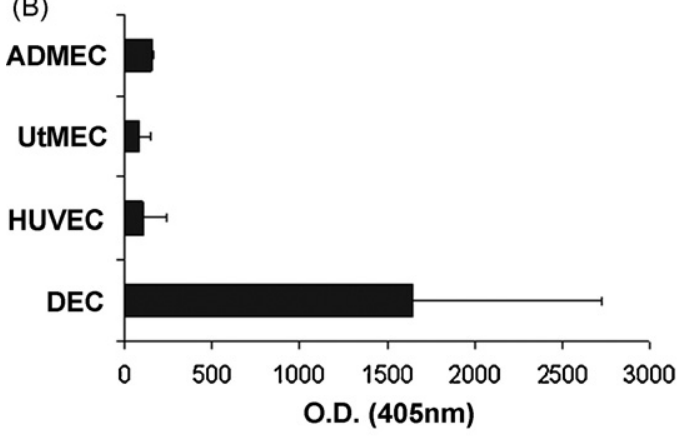

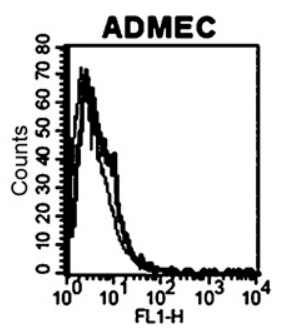

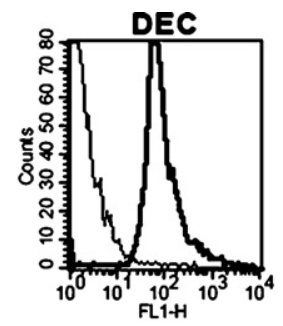

(C)

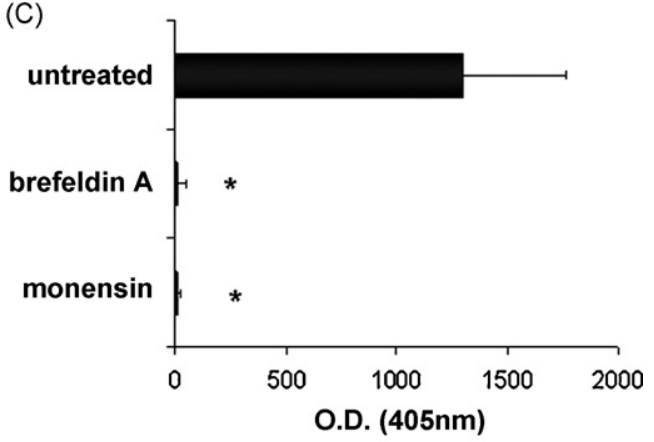

(D)

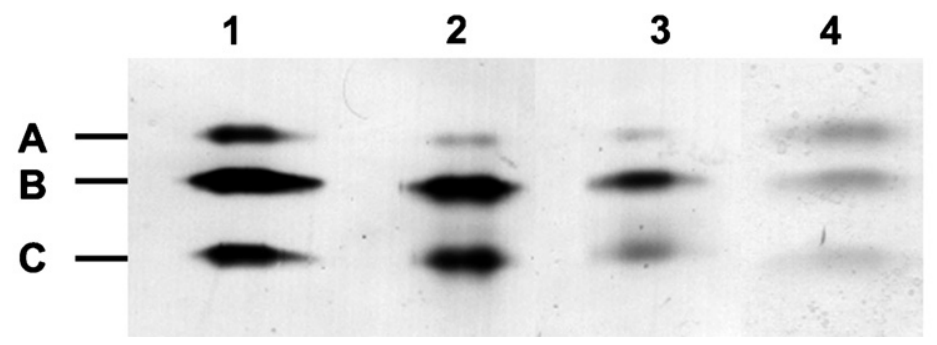

Fig. 4. Analysis of ECs for surface expression and molecular characterization of C1q. (A) Cytofluorimetric analysis of C1q expression on freshly isolated ECs (DECs, UtMECs, ADMECs, HUVECs) incubated first with mAb for C1q $(10 \mu \mathrm{g} / \mathrm{ml})$ and then with FITC-conjugated $\mathrm{F}\left(\mathrm{ab}^{\prime}\right)_{2}$ fragment of goat anti-mouse Ig (1/50). (B) ELISA on ECs using DECs, UtMECs, ADMECs and HUVECs grown to confluence and incubated with mAb anti-human C1q (10 $\mu \mathrm{g} / \mathrm{ml})$ followed by AP-conjugated goat IgG anti-mouse IgG (1/6000). For details see Section 2. (C) ELISA on a confluent monolayer of DECs incubated with $5 \mu M$ monensin, $0.5 \mu M$ brefeldin A (Sigma-Aldrich) or medium alone for $24 \mathrm{~h}$. The amount of $\mathrm{Clq}$ remaining on the cell surface was evaluated as indicated in B. ${ }^{*} P<.01$ versus untreated cells. (D) Western blot analysis of serum purified C1q from Quidel (track 1), and of C1q affinity-purified from cell supernatant (track 2) or from cell lysate (track 3). The blotted C1q bands were revealed using rabbit IgG anti-human C1q (1/1000) followed by AP-conjugated goat IgG anti rabbit IgG (1/20,000) (Sigma-Aldrich). C1q was also affinity purified from biotin-labeled DEC membranes and revealed with AP-conjugated streptavidine (1/4000) (Sigma-Aldrich) (track 4). The molecular weight of A-C chains of C1q were 29, 27 and $23 \mathrm{kDa}$ respectively.

$\mathrm{cC} 1 \mathrm{qR}$ or $\mathrm{gC} 1 \mathrm{qR}$ in the preparation of $\mathrm{C} 1 \mathrm{q}$ affinity purified from DEC lysate both by immunoblotting and by sandwich ELISA (data not shown). Heparan sulphate (HS) was another likely candidate that may provide binding sites for C1q on DECs in view of the well-known interaction of this $\mathrm{C}$ component with glycosaminoglycans (GAG) (Almeda et al., 1983). To this purpose, cells grown to confluence were treated with heparinase I, II or III or the mixture of the three enzymes for $2 \mathrm{~h}$ at $37^{\circ} \mathrm{C}$ to remove cell-surface GAG. This treatment did not affect the integrity of the cell monolayer. At the end of incubation, treated and untreated cells were examined for the presence of cellbound C1q. As shown in Fig. 5C, heparinase I proved to be the most effective in removing surface $\mathrm{Clq}$ to level of about $45 \%$ of the untreated control. This value further increased to approximately $60 \%$ in the presence of the mixture of the three heparinases. The expression of CD31 constitutively expressed on DECs was not affected by cell treatment with heparinases (data not shown).

\subsection{Clq is localized at the contact site between endovascular trophoblast and DECs and promotes trophoblast adhesion to DECs}

Having shown that $\mathrm{C} 1 \mathrm{q}$ is localized on the surface of DECs and is produced by these cells under physiologic conditions, we examined the distribution of $\mathrm{Clq}$ in vessels containing endovascular trophoblast. Triple staining of decidual vessels for C1q, for cytokeratin 7 to stain trophoblast and for CD34 to recognize ECs, revealed deposition of $\mathrm{Clq}$ at cell-cell contact within the endovascular cluster of trophoblast and at contact sites between trophoblast and ECs (Fig. 6). The latter observation led us to hypothesize that $\mathrm{Clq}$ may favour interaction of these cells. The ability of $\mathrm{Clq}$ to promote trophoblast-endothelial interaction was tested in an adhesion assay using trophoblast isolated from first trimester placenta and stained with a fluorescent dye prior to addition to a confluent monolayer of DECs. The contribution of C1q was evaluated by incubating the cells in the presence of 
(A)
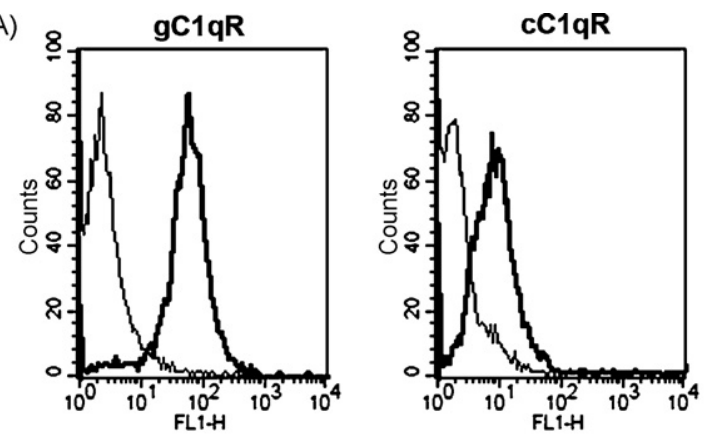

(B)

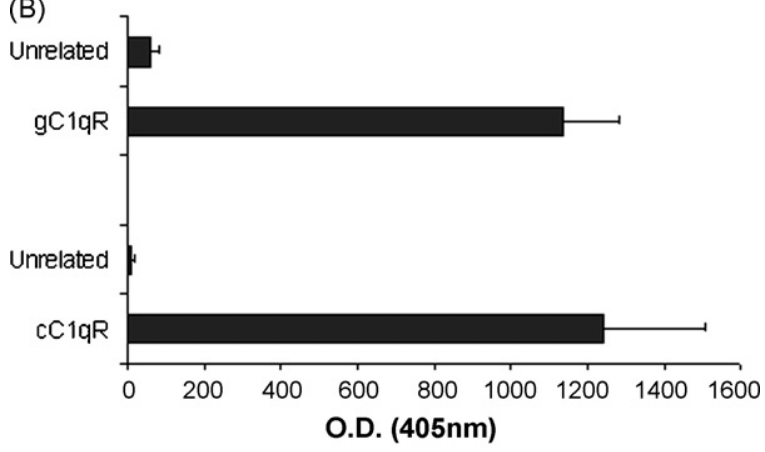

(C)

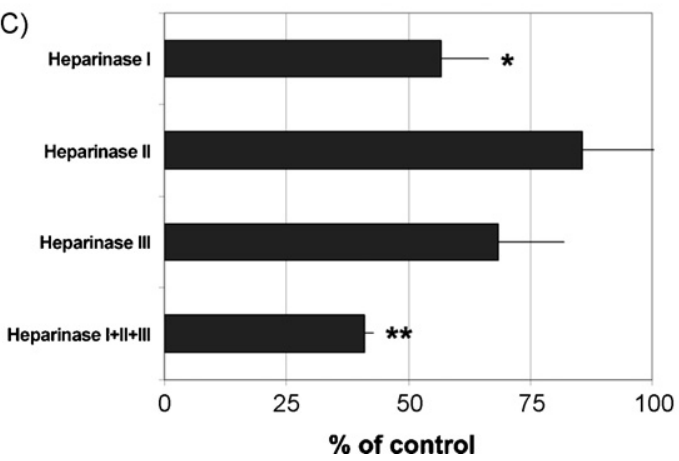

Fig. 5. Expression of C1qR on DEC and effect of heparinase on cell-bound C1q. (A) Cytofluorimetric analysis of DECs for the expression of $\mathrm{C} 1 \mathrm{q}$ receptors. The cells $\left(5 \times 10^{5}\right)$ were incubated with $\mathrm{mAb}$ 74.5.2 to gC1q-R, or rabbit anti-human $\mathrm{cC} 1 \mathrm{q}-\mathrm{R}$ antibodies. The antibodies were used at the concentration of $10 \mu \mathrm{g} / \mathrm{ml}$ to a total volume of $100 \mu \mathrm{l}$ in PBS containing 1\% BSA and their binding was revealed by $1 / 50$ FITC-conjugated goat $\mathrm{F}\left(\mathrm{ab}^{\prime}\right)_{2}$ fragments to mouse $\mathrm{IgG}$ or swine IgG anti rabbit Ig. (B) Biotinylated DEC membranes were added to microtiter plate wells coated with $\mathrm{pAb}$ anti $\mathrm{cClqR}, \mathrm{mAb}$ anti-gC1qR74.5.2 or speciesmatched control $\operatorname{IgG}(10 \mu \mathrm{g} / \mathrm{ml})$. The captured proteins were then detected using AP-conjugated streptavidin and visualized by reaction with $p$-nitrophenyl phosphate. (C) Heparinase treatment of DECs. Confluent monolayer of DECs was separately incubated with heparinase I, II or III (each at $3 \times 10^{-2}$ Units/ml) or treated with the mixture of the three enzymes for $2 \mathrm{~h}$ at $37^{\circ} \mathrm{C}$ to remove cellsurface glycosaminoglycans. Cells incubated with medium alone served as a control. The residual cell-bound C1q was measured by ELISA. Data of C1q expression on treated cells are given as percent of $\mathrm{C} 1 \mathrm{q}$ expressed on untreated cells and presented as mean \pm S.D. of triplicate samples from 3 independent experiments. ${ }^{*} P<.01,{ }^{* *} P<.001$ versus control.

goat IgG anti-C1q, which completely prevented the adhesion of trophoblast to DECs whereas antibodies to C3, used as a control, were ineffective. No inhibition was observed using antibodies to ICAM-1 constitutively expressed on DECs (Bulla et al., 2005) (data not shown). These data suggest that $\mathrm{C} 1 \mathrm{q}$ may provide a physical link between trophoblast and DECs (Fig. 7A). To further investigate the mechanism of cell-cell interaction, purified
CTBs were examined for the presence of $\mathrm{C} 1 \mathrm{q}$ receptors on the cell membrane by cytofluorimetric analysis and found to express gClq-R but not cC1q-R (Fig. 7B). Based on these results, we performed the adhesion assay using CTBs incubated either with $\mathrm{mAb} 60.11$ to $\mathrm{gC} 1 \mathrm{q}-\mathrm{R}$, that recognizes an epitope involved in the interaction with $\mathrm{C} 1 \mathrm{q}$, or $\mathrm{mAb} 74.5 .2$ to $\mathrm{gC} 1 \mathrm{qR}$ reacting with an epitope not involved in the binding of $\mathrm{C} 1 \mathrm{q}$ or with mouse isotype control IgG. The cells were gently washed prior to addition to DECs and then co-cultured for $30 \mathrm{~min}$. The data presented in Fig. 7C show that, unlike mAb 74.5.2 or the unrelated IgG, mAb 60.11 inhibited almost completely the adhesion of CTBs to DECs suggesting the involvement of this receptor in the binding of Clq to CTBs.

\section{Discussion}

$\mathrm{C} 1 \mathrm{q}$ is a recognition molecule of the $\mathrm{C}$ system and its main function is to initiate the activation of the classical pathway leading to the release of biologically active products that are primarily involved in the removal of ICs, infectious and other harmful agents. The data presented here suggest that $\mathrm{C} 1 \mathrm{q}$ has an additional role and contributes to the physiologic changes of decidual vessels that occur in placenta during the early phase of pregnancy.

The starting point for the present investigation was the observation that $\mathrm{Clq}$ was deposited on the endothelium of decidual vessels in the first trimester placentae. This is an unusual finding in physiologic conditions, such as pregnancy, because $\mathrm{C} 1 \mathrm{q}$ is usually detected on cells or tissues in pathologic situations in association with other $\mathrm{C}$ components. Deposition of $\mathrm{C} 1 \mathrm{q}$ on ECs is frequently the result of $\mathrm{C}$ activation triggered by antibodies bound to surface antigens, as we have recently shown with antibodies to $\beta 2$-glycoprotein I that are capable of inducing Cdependent thrombosis in a rat model (Fischetti et al., 2005). In the case of DECs, we failed to detect immunoglobulins and C4 co-localized with $\mathrm{C} 1 \mathrm{q}$ suggesting that $\mathrm{C}$ activation through the classical pathway is unlikely to be responsible for the binding of C1q to ECs. This observation is in agreement with the findings that quiescent cultured ECs do not activate $\mathrm{C}$ (Mold and Morris, 2001) or support a very low $\mathrm{C}$ activation (Hindmarsh and Marks, 1998; Yin et al., 2007) and is consistent with the antiinflammatory property of the endothelium maintained by cell surface and plasma C inhibitors (Fischetti and Tedesco, 2006).

The observation that deposition of $\mathrm{C} 1 \mathrm{q}$ was restricted to DECs and was not found on UtMECs from non-pregnant uterus is a clear indication that binding of C1q to DECs is a pregnancyassociated process. This conclusion is also supported by our failure to detect $\mathrm{C} 1 \mathrm{q}$ on ECs of skin and central nervous system microvessels as well as on glomerular ECs. One possible explanation for the different distribution of $\mathrm{C} 1 \mathrm{q}$ on ECs from various districts is that $\mathrm{C} 1 \mathrm{q}$ is constitutively expressed on the surface of DECs. ECs are not listed among the C1q-producing cells that include primarily macrophages (Bensa et al., 1983), fibroblasts (Skok et al., 1981), epithelial cells of the intestinal and urogenital tracts (Bing et al., 1975), follicular dendritic cells and interdigitating cells (Schwaeble et al., 1995). The finding that HUVECs, UtMECs and ADMECs express only one or two of the mRNAs 

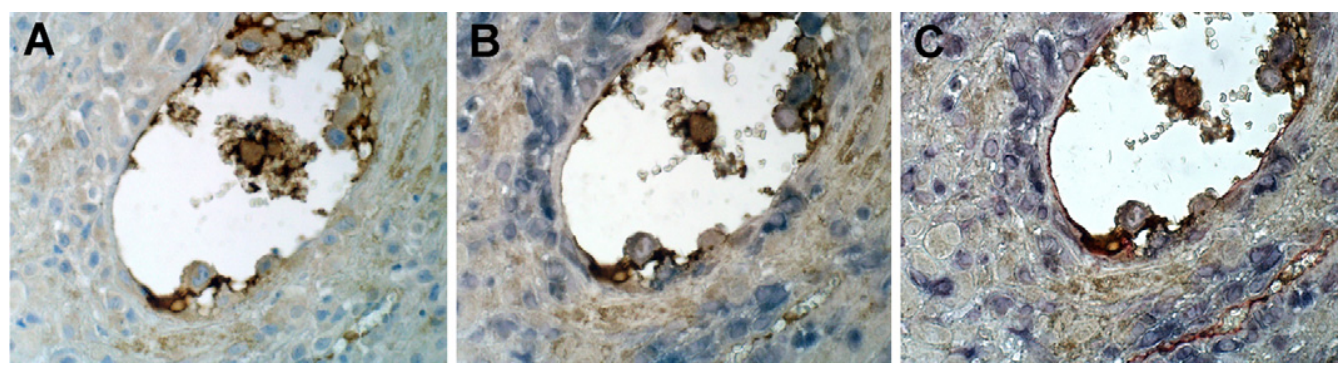

Fig. 6. Localization of $\mathrm{C} 1 \mathrm{q}$ at the contact site between endovascular trophoblast and DECs. (A) Single staining (brown) of section of maternal decidua with rabbit IgG anti-human-C1q (1/100) using the LSAB+ HRP kit to reveal bound antibodies and DAB as chromogen (brown); (B) double staining of the same section with rabbit IgG anti-human-C1q as above (brown) and mAb OU-TL 12/30 to human cytokeratin 7 (1/50) developed with APAAP Complex (Dako) and NBT/BCIP as chromogen (blue); (C) triple staining of the same section with rabbit IgG anti-human-C1q (brown), mAb OU-TL 12/30 to human cytokeratin 7 (blue) and mAb QBEnd/10 anti-human-CD34 using the PAP, Mouse Monoclonal Complex (Dako) as a revealing system and AEC as chromogen (red). The sections were counterstained with hematoxylin. Original magnifications: (A-C) 400x.

(A)

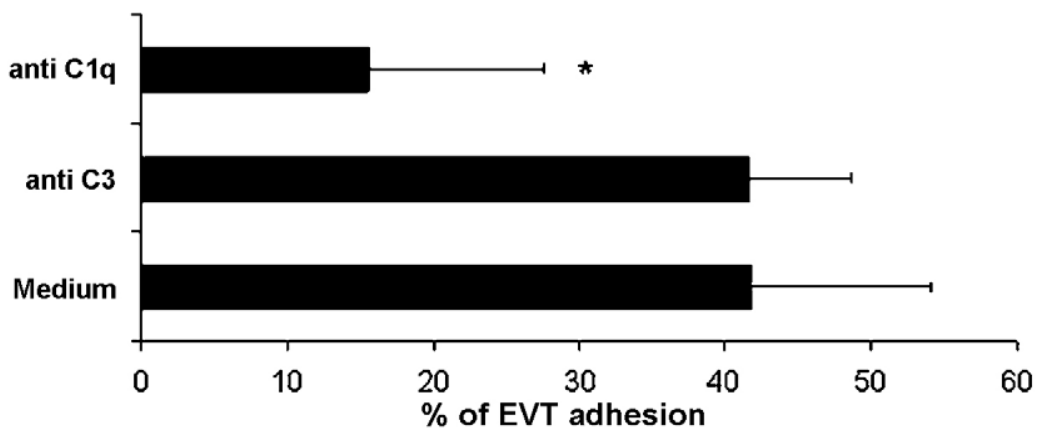

(B)
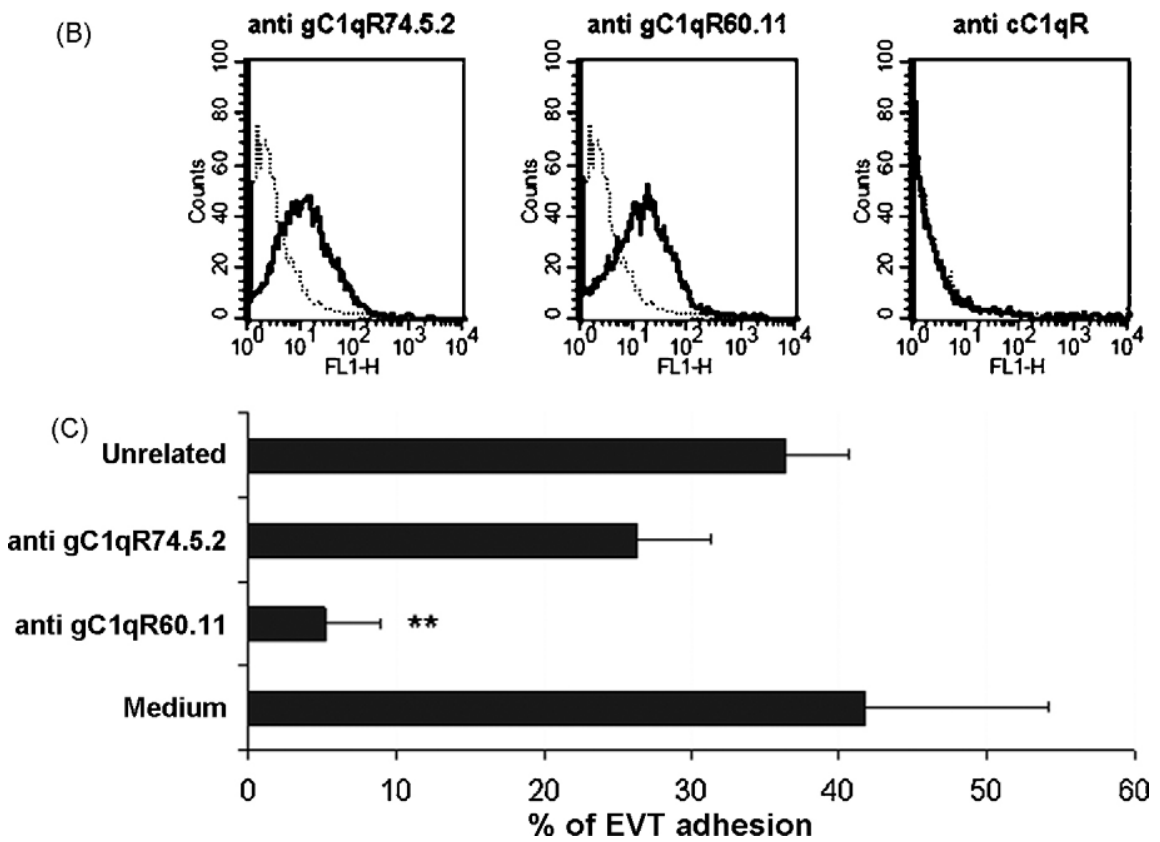

Fig. 7. C1q mediates trophoblast-DEC interaction (A) CTBs were labeled with Fast DiI and allowed to adhere to confluent DECs for $30 \mathrm{~min}$ at $37^{\circ} \mathrm{C}$ in the presence of goat IgG to $\mathrm{C} 1 \mathrm{q}$ and $\mathrm{C} 3(40 \mu \mathrm{g} / \mathrm{ml})$ or medium alone. The results are given as percent of cell adhesion. (B) Cytofluorimetric analysis of CTBs purified from first trimester placenta for the expression of $\mathrm{Clq}$ receptors. The cells $\left(5 \times 10^{5}\right)$ were incubated with mAb 74.5 .2 or mAb 60.11, both directed to gC1q-R, or rabbit anti-human cClq-R antibodies. All the antibodies were used at the concentration of $10 \mu \mathrm{g} / \mathrm{ml}$ to a total volume of $100 \mu 1$ in PBS containing $1 \%$ BSA. Binding of the antibodies was revealed by FITC-conjugated goat $\mathrm{F}\left(\mathrm{ab}^{\prime}\right)_{2}$ fragments to mouse IgG or swine IgG anti rabbit Ig. Both antibodies were used at $1 / 50$. (C) Percent adhesion of labeled CTBs to confluent DECs in the presence of mAb 60.11, mAb 74.5.2 or mouse IgG1 isotype control ( $40 \mu \mathrm{g} / \mathrm{ml})$. The data in A and C are presented as mean \pm S.D. of triplicate samples from at least 4 independent experiments. ${ }^{*} P<.01,{ }^{* *} P<.001$ versus cells incubated with anti-C3 antibody (A) or mouse IgG1 (C). 
required for the synthesis of the three chains of $\mathrm{C} 1 \mathrm{q}$ confirmed that these cells are unable to produce this $\mathrm{C}$ component. DECs are a notable exception because they not only express mRNAs for $\mathrm{A}-\mathrm{C}$ chains of $\mathrm{C} 1 \mathrm{q}$, but also synthesize $\mathrm{C} 1 \mathrm{q}$, which can therefore be regarded as a marker of cell decidualization.

The presence of a substantial amount of C1q bound to DECs is reminiscent of $\mathrm{Clq}$ detected on the surface of human and guinea pig peritoneal macrophages several years ago by Loos et al. (1981). The macrophage-associated C1q was later reported to derive from secreted $\mathrm{C} 1 \mathrm{q}$ and to share with the soluble molecule the three chain structure with the only difference that the B chain had a molecular weight approximately 1000 Da lower (Martin et al., 1987). Our findings indicate that DECs-bound C1q resembles to a large extent the molecule expressed on macrophages, but has some distinct features. They both contain the three chains $\mathrm{A}-\mathrm{C}$ and are present on the cell membrane. However, DECs C1q differs from macrophage $\mathrm{C} 1 \mathrm{q}$ for the molecular weight similar to that of fluid phase $\mathrm{C} 1 \mathrm{q}$ and also because it is easily released from the surface of DECs after short incubation in $\mathrm{pH} 2.5$ buffer (Haigler et al., 1980), suggesting that its binding to the cell surface is reversible.

Two distinct receptors recognizing either the collagen tail (Malhotra, 1993; Peerschke et al., 1993) or the globular heads of C1q (Oroszlan et al., 2007; Peerschke et al., 1996) have been identified on ECs. Binding of C1q to C1qRs has been shown to induce diverse biologic effects including cell adhesion and spreading, expression of the adhesion molecules E-selectin, ICAM-1 and VCAM-1 (Lozada et al., 1995) and production of IL-6, IL-8 and monocyte chemoattractant protein-1 (van den Berg et al., 1998). However, $\mathrm{cC} 1 \mathrm{qR}$ and $\mathrm{gC} 1 \mathrm{qR}$ are unlikely to be involved in the binding of $\mathrm{C} 1 \mathrm{q}$ because we failed to identify bands corresponding to either of the two C1qRs in western blot analysis of C1q purified from DECs by affinity chromatography and to obtain positive signals when the same preparation was examined by a sandwich capture ELISA using antibodies to $\mathrm{C} 1 \mathrm{q}$ and to each $\mathrm{C} 1 \mathrm{qR}$. This was not surprising since these receptors are found predominantly inside the cell and are expressed on resting ECs in a low number that increases upon cell exposure to pro-inflammatory stimuli, such as LPS, TNF $\alpha$ and IFN $\gamma$ (Guo et al., 1999) although this remains a controversial issue (Oroszlan et al., 2007). In addition, C1q has been shown to bind to C1qRs with high affinity only when immobilized on polystyrene plate, heat-treated or bound to ICs, suggesting that the conformational changes of the molecule may favour its interaction with the ligand (Lozada et al., 1995; Steino et al., 2004; van den Berg et al., 1998). Heparan sulphates present on the surface of ECs offer an alternative to $\mathrm{C} 1 \mathrm{qR}$ in binding $\mathrm{Clq}$, as suggested by our data showing that treatment of DECs with heparinase removes a substantial portion of bound C1q. This is in line with previously published data providing evidence for the interaction of $\mathrm{C} 1 \mathrm{q}$ with mucopolysaccharides including heparin sulphate and dermatan sulphate (Almeda et al., 1983).

Immunohistochemical detection of $\mathrm{Clq}$ at the contact site between endovascular trophoblast and DECs in the absence of $\mathrm{C}$ activation was an unexpected finding and raised the question whether C1q may play a role in the cross-talk between these two cell types. A multi-step process develops in the early phase of pregnancy that leads endovascular trophoblast to adhere to ECs and to migrate through the inter-endothelial junctions of spiral arteries reaching subendothelial position (Bulla et al., 2005). As a result of trophoblast migration and localization on the basal membrane, ECs are partially replaced and a mosaic vessel is formed resembling the vessels containing metastatic tumor cells (Chang et al., 2000). Such a complex process may require multiple cell-cell interactions that can be brought about by interacting molecules expressed on trophoblast and DECs as well as by proteins spanning across the two cell types. We have previously shown that VE-cadherin expressed on endovascular trophoblast establish homotypic interaction with the same molecule on DECs and this in turn promotes adhesion and transendothelial migration of trophoblast (Bulla et al., 2005). VE-cadherin is expressed on invasive trophoblast as part of a program that leads these cells to change their pattern of adhesion molecules on their way from the cell column to their vascular localization as endovascular trophoblast (Zhou et al., 1997b). We believe that C1q expressed on the surface of DECs serves a similar purpose except that in this case $\mathrm{Clq}$ itself is able to create a molecular bridge between EVT and DECs. The critical role played by this $\mathrm{C}$ component in trophoblast-DEC interaction is supported by the finding that adhesion of CTBs to DECs is inhibited by antibodies to C1q. Our data suggest that this is made possible by the expression of $\mathrm{gClqR}$ on CTBs that reacts with $\mathrm{C} 1 \mathrm{q}$ already bound to DECs recognizing the globular heads as suggested by the blocking effect seen with mAb to the globular portion of the molecule. The critical role played by $\mathrm{C} 1 \mathrm{q}$ in trophoblast-DEC interaction is also supported by the finding that adhesion of CTBs to DECs was inhibited by mAb 60.11, that recognize a $\mathrm{C} 1 \mathrm{q}$ binding site on $\mathrm{gC} 1 \mathrm{qR}$, but not by $\mathrm{mAb}$ 74.5.2, that react with an epitope of $\mathrm{gClqR}$ involved in the reaction with the high molecular weight kininogen (Joseph et al., 1996).

In conclusion, we have provided data indicating that endothelial cells of spiral arteries acquire the ability to synthesize $\mathrm{Clq}$ during pregnancy. The $\mathrm{C} 1 \mathrm{q}$ binds avidly to the cell surface and acts as physical link between endovascular trophoblast and DECs.

\section{Acknowledgements}

We thank Silvia Smiroldo, Francesca Colombo and Sara Sacco of the Department of Reproductive and Developmental Sciences for providing the placenta samples. This work was supported by the European NoE "EMBIC" within FP6 (contract number LSHN-CT-2004-512040), AIRC, and COFIN 2005 provided by Ministero dell'Istruzione, Università e Ricerca (MIUR) and "Progetto giovani ricercatori", provided by University of Trieste.

\section{References}

Almeda, S., Rosenberg, R.D., Bing, D.H., 1983. The binding properties of human complement component C1q Interaction with mucopolysaccharides. J. Biol. Chem. 258, 785-791. 
Asch, A.S., Kinoshita, T., Jaffe, E.A., Nussenzweig, V., 1986. Decayaccelerating factor is present on cultured human umbilical vein endothelial cells. J. Exp. Med. 163, 221-226.

Bensa, J.C., Reboul, A., Colomb, M.G., 1983. Biosynthesis in vitro of complement subcomponents $\mathrm{C} 1 \mathrm{q} \mathrm{C} 1 \mathrm{~s}$ and $\mathrm{C} 1$ inhibitor by resting and stimulated human monocytes. Biochem. J. 216, 385-392.

Bing, D.H., Spurlock, S.E., Bern, M.M., 1975. Synthesis of the first component of complement by primary cultures of human tumors of the colon and urogenital tract and comparable normal tissue. Clin. Immunol. Immunopathol. 4, 341-351.

Bossi, F., Fischetti, F., Pellis, V., Bulla, R., Ferrero, E., Mollnes, T.E., Regoli, D., Tedesco, F., 2004. Platelet-activating factor and kinin-dependent vascular leakage as a novel functional activity of the soluble terminal complement complex. J. Immunol. 173, 6921-6927.

Bradford, M.M., 1976. A rapid and sensitive method for the quantitation of microgram quantities of protein utilizing the principle of protein-dye binding. Anal. Biochem. 72, 248-254.

Bulla, R., Villa, A., Bossi, F., Cassetti, A., Radillo, O., Spessotto, P., De Seta, F., Guaschino, S., Tedesco, F., 2005. VE-cadherin is a critical molecule for trophoblast-endothelial cell interaction in decidual spiral arteries. Exp. Cell Res. 303, 101-113.

Chang, Y.S., di Tomaso, E., McDonald, D.M., Jones, R., Jain, R.K., Munn, L.L., 2000. Mosaic blood vessels in tumors: frequency of cancer cells in contact with flowing blood. Proc. Natl. Acad. Sci. U.S.A. 97, 14608-14613.

Daha, M.R., Miltenburg, A.M., Hiemstra, P.S., Klar-Mohamad, N., Van Es, L.A., Van Hinsbergh, V.W., 1988. The complement subcomponent C1q mediates binding of immune complexes and aggregates to endothelial cells in vitro. Eur. J. Immunol. 18, 783-787.

Dobrina, A., Pausa, M., Fischetti, F., Bulla, R., Vecile, E., Ferrero, E., Mantovani, A., Tedesco, F., 2002. Cytolytically inactive terminal complement complex causes transendothelial migration of polymorphonuclear leukocytes in vitro and in vivo. Blood 99, 185-192.

Feng, X., Tonnesen, M.G., Peerschke, E.I., Ghebrehiwet, B., 2002. Cooperation of $\mathrm{C} 1 \mathrm{q}$ receptors and integrins in $\mathrm{C} 1 \mathrm{q}-$-mediated endothelial cell adhesion and spreading. J. Immunol. 168, 2441-2448.

Fischetti, F., Durigutto, P., Pellis, V., Debeus, A., Macor, P., Bulla, R., Bossi, F., Ziller, F., Sblattero, D., Meroni, P., Tedesco, F., 2005. Thrombus formation induced by antibodies to beta2-glycoprotein $\mathrm{I}$ is complement dependent and requires a priming factor. Blood 106, 2340-2346.

Fischetti, F., Tedesco, F., 2006. Cross-talk between the complement system and endothelial cells in physiologic conditions and in vascular diseases. Autoimmunity 39, 417-428.

Ghebrehiwet, B., Lu, P.D., Zhang, W., Lim, B.L., Eggleton, P., Leigh, L.E., Reid, K.B., Peerschke, E.I., 1996. Identification of functional domains on $\mathrm{gC1Q}$ $\mathrm{R}$, a cell surface protein that binds to the globular "heads" of $\mathrm{C} 1 \mathrm{Q}$, using monoclonal antibodies and synthetic peptides. Hybridoma 15, 333-342.

Guo, W.X., Ghebrehiwet, B., Weksler, B., Schweitzer, K., Peerschke, E.I., 1999. Up-regulation of endothelial cell binding proteins/receptors for complement component C1q by inflammatory cytokines. J. Lab. Clin. Med. 133, 541-550.

Haigler, H.T., Maxfield, F.R., Willingham, M.C., Pastan, I., 1980. Dansylcadaverine inhibits internalization of 125I-epidermal growth factor in BALB 3T3 cells. J. Biol. Chem. 255, 1239-1241.

Hamilton, K.K., Ji, Z., Rollins, S., Stewart, B.H., Sims, P.J., 1990. Regulatory control of the terminal complement proteins at the surface of human endothelial cells: neutralization of a C5b-9 inhibitor by antibody to CD59. Blood $76,2572-2577$.

Hattori, R., Hamilton, K.K., McEver, R.P., Sims, P.J., 1989. Complement proteins C5b-9 induce secretion of high molecular weight multimers of endothelial von Willebrand factor and translocation of granule membrane protein GMP-140 to the cell surface. J. Biol. Chem. 264, 9053-9060.

Hindmarsh, E.J., Marks, R.M., 1998. Complement activation occurs on subendothelial extracellular matrix in vitro and is initiated by retraction or removal of overlying endothelial cells. J. Immunol. 160, 6128-6136.

Hustin, J., Foidart, J.M., Lambotte, R., 1983. Maternal vascular lesions in pre-eclampsia and intrauterine growth retardation: light microscopy and immunofluorescence. Placenta 4 Spec No, 489-498.

Jokiranta, T.S., Cheng, Z.Z., Seeberger, H., Jozsi, M., Heinen, S., Noris, M., Remuzzi, G., Ormsby, R., Gordon, D.L., Meri, S., Hellwage, J., Zipfel, P.F.,
2005. Binding of complement factor $\mathrm{H}$ to endothelial cells is mediated by the carboxy-terminal glycosaminoglycan binding site. Am. J. Pathol. 167, 1173-1181.

Joseph, K., Ghebrehiwet, B., Peerschke, E.I., Reid, K.B., Kaplan, A.P., 1996. Identification of the zinc-dependent endothelial cell binding protein for high molecular weight kininogen and factor XII: identity with the receptor that binds to the globular "heads" of C1q (gC1q-R). Proc. Natl. Acad. Sci. U.S.A. 93, 8552-8557.

Kaul, M., Loos, M., 2001. Expression of membrane C1q in human monocytederived macrophages is developmentally regulated and enhanced by interferon-gamma. FEBS Lett. 500, 91-98.

Kilgore, K.S., Flory, C.M., Miller, B.F., Evans, V.M., Warren, J.S., 1996. The membrane attack complex of complement induces interleukin- 8 and monocyte chemoattractant protein-1 secretion from human umbilical vein endothelial cells. Am. J. Pathol. 149, 953-961.

Kitzmiller, J.L., Watt, N., Driscoll, S.G., 1981. Decidual arteriopathy in hypertension and diabetes in pregnancy: immunofluorescent studies. Am. J. Obstet. Gynecol. 141, 773-779.

Kraling, B.M., Jimenez, S.A., Sorger, T., Maul, G.G., 1994. Isolation and characterization of microvascular endothelial cells from the adult human dermis and from skin biopsies of patients with systemic sclerosis. Lab. Invest. 71, $745-754$.

Laemmli, U.K., 1970. Cleavage of structural proteins during the assembly of the head of bacteriophage T4. Nature 227, 680-685.

Lan, H.Y., Mu, W., Nikolic-Paterson, D.J., Atkins, R.C., 1995. A novel, simple, reliable, and sensitive method for multiple immunoenzyme staining: use of microwave oven heating to block antibody crossreactivity and retrieve antigens. J. Histochem. Cytochem. 43, 97-102.

Langeggen, H., Pausa, M., Johnson, E., Casarsa, C., Tedesco, F., 2000. The endothelium is an extrahepatic site of synthesis of the seventh component of the complement system. Clin. Exp. Immunol. 121, 69-76.

Loos, M., Storz, R., Muller, W., Lemmel, E.M., 1981. Immunofluorescence studies on the subcomponents of the first component of complement (C1): detection of $\mathrm{C} 1 \mathrm{q}$ and $\mathrm{C} 1 \mathrm{~s}$ in different cells of biopsy material and on human as well as on guinea pig peritoneal macrophages. Immunobiology 158 , 213-224.

Lozada, C., Levin, R.I., Huie, M., Hirschhorn, R., Naime, D., Whitlow, M., Recht, P.A., Golden, B., Cronstein, B.N., 1995. Identification of C1q as the heat-labile serum cofactor required for immune complexes to stimulate endothelial expression of the adhesion molecules E-selectin and intercellular and vascular cell adhesion molecules 1. Proc. Natl. Acad. Sci. U.S.A. 92, 8378-8382

Lyall, F., Bulmer, J.N., Duffie, E., Cousins, F., Theriault, A., Robson, S.C., 2001. Human trophoblast invasion and spiral artery transformation: the role of PECAM-1 in normal pregnancy, preeclampsia, and fetal growth restriction. Am. J. Pathol. 158, 1713-1721.

Malhotra, R., 1993. Collectin receptor (C1q receptor): structure and function. Behring Inst. Mitt., 254-261.

Martin, H., Heinz, H.P., Reske, K., Loos, M., 1987. Macrophage C1q: characterization of a membrane form of $\mathrm{C} 1 \mathrm{q}$ and of multimers of $\mathrm{C} 1 \mathrm{q}$ subunits. $\mathrm{J}$. Immunol. 138, 3863-3867.

McNearney, T., Ballard, L., Seya, T., Atkinson, J.P., 1989. Membrane cofactor protein of complement is present on human fibroblast, epithelial, and endothelial cells. J. Clin. Invest. 84, 538-545.

Michel, M.Z., Khong, T.Y., Clark, D.A., Beard, R.W., 1990. A morphological and immunological study of human placental bed biopsies in miscarriage. Br. J. Obstet. Gynaecol. 97, 984-988.

Mold, C., Morris, C.A., 2001. Complement activation by apoptotic endothelial cells following hypoxia/reoxygenation. Immunology 102, 359-364.

Monsinjon, T., Gasque, P., Chan, P., Ischenko, A., Brady, J.J., Fontaine, M.C., 2003. Regulation by complement C3a and C5a anaphylatoxins of cytokine production in human umbilical vein endothelial cells. FASEB J. 17, 1003-1014.

Noyes, R.W., Hertig, A.T., Rock, J., 1975. Dating the endometrial biopsy. Am. J. Obstet. Gynecol. 122, 262-263.

Oroszlan, M., Daha, M.R., Cervenak, L., Prohaszka, Z., Fust, G., Roos, A., 2007. MBL and C1q compete for interaction with human endothelial cells. Mol. Immunol. 44, 1150-1158. 
Peerschke, E.I., Malhotra, R., Ghebrehiwet, B., Reid, K.B., Willis, A.C., Sim, R.B., 1993. Isolation of a human endothelial cell C1q receptor (C1qR). J. Leukoc. Biol. 53, 179-184.

Peerschke, E.I., Smyth, S.S., Teng, E.I., Dalzell, M., Ghebrehiwet, B., 1996. Human umbilical vein endothelial cells possess binding sites for the globular domain of C1q. J. Immunol. 157, 4154-4158.

Pijnenborg, R., Vercruysse, L., Hanssens, M., 2006. The uterine spiral arteries in human pregnancy: facts and controversies. Placenta 27, 939-958.

Schraufstatter, I.U., Trieu, K., Sikora, L., Sriramarao, P., DiScipio, R., 2002. Complement $\mathrm{c} 3 \mathrm{a}$ and $\mathrm{c} 5 \mathrm{a}$ induce different signal transduction cascades in endothelial cells. J. Immunol. 169, 2102-2110.

Schwaeble, W., Schafer, M.K., Petry, F., Fink, T., Knebel, D., Weihe, E., Loos, M., 1995. Follicular dendritic cells, interdigitating cells, and cells of the monocyte-macrophage lineage are the C1q-producing sources in the spleen Identification of specific cell types by in situ hybridization and immunohistochemical analysis. J. Immunol. 155, 4971-4978.

Selvan, R.S., Kapadia, H.B., Platt, J.L., 1998. Complement-induced expression of chemokine genes in endothelium: regulation by IL-1-dependent and independent mechanisms. J. Immunol. 161, 4388-4395.

Sheppard, B.L., Bonnar, J., 1981. An ultrastructural study of utero-placental spiral arteries in hypertensive and normotensive pregnancy and fetal growth retardation. Br. J. Obstet. Gynaecol. 88, 695-705.

Skok, J., Solomon, E., Reid, K.B., Thompson, R.A., 1981. Distinct genes for fibroblast and serum C1q. Nature 292, 549-551.

Steino, A., Jorgensen, C.S., Laursen, I., Houen, G., 2004. Interaction of C1q with the receptor calreticulin requires a conformational change in C1q. Scand. J. Immunol. 59, 485-495.

Stokol, T., O'Donnell, P., Xiao, L., Knight, S., Stavrakis, G., Botto, M., von Andrian, U.H., Mayadas, T.N., 2004. C1q governs deposition of circulating immune complexes and leukocyte Fcgamma receptors mediate subsequent neutrophil recruitment. J. Exp. Med. 200, 835-846.

Tedesco, F., Pausa, M., Nardon, E., Introna, M., Mantovani, A., Dobrina, A., 1997. The cytolytically inactive terminal complement complex activates endothelial cells to express adhesion molecules and tissue factor procoagulant activity. J. Exp. Med. 185, 1619-1627.

van den Berg, R.H., Faber-Krol, M.C., Sim, R.B., Daha, M.R., 1998. The first subcomponent of complement, C1q, triggers the production of IL-8, IL-6, and monocyte chemoattractant peptide- 1 by human umbilical vein endothelial cells. J. Immunol. 161, 6924-6930.

Wells, M., Bennett, J., Bulmer, J.N., Jackson, P., Holgate, C.S., 1987. Complement component deposition in uteroplacental (spiral) arteries in normal human pregnancy. J. Reprod. Immunol. 12, 125-135.

Yin, W., Ghebrehiwet, B., Weksler, B., Peerschke, E.I., 2007. Classical pathway complement activation on human endothelial cells. Mol. Immunol. 44, 2228-2234.

Zhou, Y., Damsky, C.H., Fisher, S.J., 1997a. Preeclampsia is associated with failure of human cytotrophoblasts to mimic a vascular adhesion phenotype. One cause of defective endovascular invasion in this syndrome? J. Clin. Invest. 99, 2152-2164.

Zhou, Y., Fisher, S.J., Janatpour, M., Genbacev, O., Dejana, E., Wheelock, M., Damsky, C.H., 1997b. Human cytotrophoblasts adopt a vascular phenotype as they differentiate. A strategy for successful endovascular invasion? J. Clin. Invest. 99, 2139-2151.

Ziccardi, R.J., Cooper, N.R., 1979. Active disassembly of the first complement component, C-1, by C-1 inactivator. J. Immunol. 123, 788-792.

Ziccardi, R.J., Tschopp, J., 1982. The dissociation properties of native C1. Biochem. Biophys. Res. Commun. 107, 618-623. 